\title{
HISTÓRIAS DE LITERATURA: conflitos e caminhos
}

Heidrun Krieger Olinto

No contexto das reflexões que gostaria de apresentar neste congresso, pareceme oportuno indagar mais uma vez: quais poderiam ser hoje as motivações para escrever histórias (de literatura) e que tipo de argumentos poderiam ser convenientes para justificar determinadas escolhas que privilegiam e definem modos específicos de sua compreensão, de sua função e dos modos de sua representação?

Se numa retrospectiva histórica consideramos o conceito de história em sua tradução no singular coletivo - a história - como herança do século XVIII, ou, se quisermos, do projeto da modernidade que então se delineava, vale lembrar os pressupostos do novo batismo que exibia no próprio nome o gesto de subsumir, numa representação única, a História, a multiplicidade de histórias no plural vistas, então, como mera coleção sem nexo. A concepção de uma humanidade una e de sua história, tornada visível, portanto, na substituição do plural pelo singular coletivo em sua condição de substantivo, implicava, ao mesmo tempo, um plano único à mera coleção de feitos e eventos, vistos, em sua coexistência simultânea, como sem nexo e ao acaso.

Se acrescentarmos a essa idéia a emergência da sensação do presente afastando-se do passado como qualitativamente diferente e, neste quadro, a história como movimento progressivo em direção à emancipação da humanidade como um todo, via 
razão, pela superação dos erros identificados no passado, torna-se, também, compreensível o acento dado, e implícito, ao valor prático e moral da história para o cidadão cosmopolita e, por extensão, para a humanidade como um todo. Mais ainda a partir da intenção declarada neste projeto, de promover a solidariedade entre os homens diminuindo a dominação, idealizada numa linha diacrônica ascendente que apontava para o futuro.

A nova autoconsciência do século favorecia, ainda neste espírito, uma aproximação com certos princípios assumidos pelas ciências naturais, entre elas, a categoria da causalidade, que resultava, ao mesmo tempo, no distanciamento da casualidade do ponto de vista do sujeito cognitivo individual, inserido nas vicissitudes e aleatoriedades de sua vida cotidiana particular. Desde então, a história passava a ser projetada como processo evolutivo unilinear da humanidade em seu conjunto, abrangendo passado, presente e futuro em torno da idéia do progresso, e oferecendo um modelo capaz de integrar as múltiplas ações humanas dispersas e articuladas ao acaso, numa representação orientada pela razão.

Hoje, numa perspectiva crítica radical, essa idéia de uma História geral não passaria de uma ideologia eurocêntrica, marcada pelo estigma da destruição de outras formas de identidade cultural. Numa ótica mais branda e neutra, sem o peso político da primeira, poderíamos formular o problema talvez assim: Esse modelo de história perdeu a sua força de persuasão. Em todo caso, as novas formas de sua própria escrita parecem atestar esta hipótese.

Um dos modelos mais acabados de sua configuração anterior revela-se explicitamente na estrutura privilegiada da narrativa que pressupõe a ação dos personagens numa seqüência lógica, linear e progressiva. E é por isso que me parece sugestivo um olhar sobre a narrativa épica e os argumentos de sua defesa exemplar, ainda dois séculos depois. A coletânea de textos de Geog Lukács, O realismo hoje (1957), resultado de uma série de conferências dadas entre 1955 e 1956, e discutida com fervor durante a década subsequente, oferece talvez certas pistas. Em seu conjunto, o autor reafirma algumas posições defendidas de modo explícito no texto clássico "Narrar ou descrever?", de 1936. O ensaio, que se refere à problematização de procedimentos artísticos adequados ao escritor engajado no projeto socialista de refletir a realidade, traduz, neste projeto, a tentativa de solucionar a contradição entre uma estética normativa essencialmente a-histórica e uma teoria marxista da história que se entende integrada ao processo do desenvolvimento global da sociedade. 
O acento, na tematização dessa questão, sobre estratégias artísticas foi condicionado pelos movimentos vanguardistas europeus que elegeram a forma descritiva como modo de representação predileto. Lukács confronta essa opção com os procedimentos narrativos característicos do realismo clássico exemplificado, para ele, pelas obras de Goethe, Balzac, Stendhal e Tolstói. Na sua argumentação, esses dois modos de representar - narrar e descrever - são identificados respectivamente com duas posturas divergentes do escritor face aos problemas da vida social: participar ou observar. No primeiro caso, o narrador oferece uma figuração da totalidade do real a partir da perspectiva final, ordenando as partes essenciais numa unidade orgânica legitimada pelo modo narrativo. Em contrapartida, o modelo descritivo favorece a emergência de uma realidade presente na forma de montagem. Uma realidade sem nexo, imagens estáticas, naturezas mortas, quadros pendurados lado a lado, sem relação explícita, sem explicação. Esse modelo experimental, incapaz de promover uma visão dialética da sociedade em sua integridade e totalidade orgânica - onde o presente se constitui a partir do passado e o futuro se constitui a partir do presente representa, ao contrário, a sua inevitável dissolução. Representa o fracasso da luta a favor de um realismo crítico "verdadeiro como a vida" (Lukács1957: 84). Para que a literatura possa oferecer uma representação adequada dessa realidade e dotada de unidade e sentido, é preciso que o escritor assuma uma perspectiva seletiva que revele a sua postura dinâmica face ao mundo em constante progresso .

A distância que hoje nos separa dessas convicções epistemológicas, morais e estéticas pode ser conferida no ideário de uma nova produção literária então emergente. O nouveau roman, circulando na Europa também com o rótulo Escola do olhar, tinha excluído, além da metáfora como tradução retórica mais visível de uma profundidade essencial, o próprio procedimento narrativo e, com ele, a possibilidade de uma estrutura contínua ascendente, baseada na presença do narrador como garantia de uma visão retrospectiva, orgânica, da unidade e totalidade, repletas de sentido. O romance Composition I do escritor francês Marc Saporta, publicado em 1962, exibia as novas convicções de modo exemplar e radical a partir da própria configuração material. O experimento lendário, consistindo de 150 folhas soltas sem numeração, foi vivenciado na época como "verdadeiro pesadelo bibliotecário" (Heilbrig 1998: 83). O escritor, ao libertar as páginas do romance de sua encadernação, rompia com uma das convenções mais tradicionais do livro impresso: a sua leitura linear imposta pelo princípio de seqüencialidade das palavras. Um pequeno manual de instruções, dirigido aos eventuais usuários, convidava a embaralhar as páginas como os jogadores de 
cartas, ao acaso, gozando os pequenos ensaios, erros e surpresas na construção de sua própria história, aleatória, mutante, imprevisível, sem princípio e fim. Como a vida.

$\mathrm{Na}$ época o experimento foi ironizado ou celebrado como forma visionária ao indicar o meio que permite ao romance superar a sua, até então, inevitável, linearidade. Pela grande maioria Composition I nunca foi lido, tratado com indiferença ou esquecido, ainda que a estabilidade e integridade do texto impresso estavam sendo questionadas, quase na mesma época, ao nível da própria teorização, pelo acento colocado sobre o papel ativo do leitor, não constrangido, necessariamente, pelos mesmos princípios de linearidade.

Um segundo argumento permite atualizar os efeitos desse romance experimental. Além da rejeição de uma narrativa cronológica seqüencial pela experiência da leitura aleatória de folhas soltas sem paginação, capaz de estimular múltiplas possibilidades de ordenação do processo de leitura (Pepper 1984: 182), o romance exibe a sua estrutura concreta na esfera da experiência sensorial material. Esse afastamento de uma leitura alegórica baseada na construção de sentido a favor da experiência de uma nova sensibilidade, marginalizava, de certa maneira, uma concepção da arte como crítica da vida identificando uma de suas funções básicas como construção de construção de ideais morais, sociais e políticos.

Num horizonte de expectativa semelhante dos anos 60 situa-se o famoso texto de Susan Sontag "Uma cultura e a nova sensibilidade" (1965) que enuncia expressamente uma transformação da função da arte como instrumento de modificar a consciência e organizar novos modos de sensibilidade. Nesta ótica a arte entende-se como extensão da vida; não perde necessariamente a sua função de avaliação moral, no entanto, essa, segundo Sontag, se tornaria menos exagerada. Mas o que esse abrandamento sacrificaria em termos de explicitação discursiva ganharia, por outro lado, em precisão e força subliminar. "Pois nós somos o que somos capazes de ver (ouvir, tocar, cheirar, sentir) inclusive mais forte e mais profundamente do que somos o conjunto das idéias que armazenamos em nossa cabeça" (345). Aos possíveis "humanistas ultrajados" o seu consolo: "Uma obra de arte não deixa de ser um momento na consciência da humanidade no qual a consciência moral é compreendida apenas como uma das funções da consciência."(346).

Uma avaliação dos novos experimentos historiográficos que se situam explicitamente numa perspectiva dos estudos atuais da literatura permite estabelecer certos vínculos com as reflexões anteriores, enfatizando novas predileções e plausibilidades que marcam o cenário intelectual presente e desconfirmam convicções antes assumi- 
das. Mas o que, afinal, podemos assumir como literatura quando hoje falamos dela? Uma pergunta que precede, necessariamente, indagações críticas sobre histórias de literatura em relação a seus pressupostos, intenções, formas de escrita e formato, explicitados em discursos teóricos programáticos que orientam - ou não - a prática historiográfica (literária), precisa referir-se ao estatuto do próprio fenômeno literário ou, pelo menos, às possibilidades de se circunscrevê-lo.

Um breve olhar sobre o campo dos estudos de literatura revela de imediato que uma parte da desordem gigantesca da casa se auto-expressa de modo palpável na forma, na organização e no estilo priorizados pelos diversos manuais de teoria da literatura em circulação, que se transformaram, cada vez mais, em coletâneas de ensaios de autoria e temática múltiplas. Trata-se de produtos que sinalizam previa e simultaneamente descompromissos com filiações duradouras, atestando a substituição da voz autoral particular pelo consenso/dissenso de subgrupos de uma comunidade sem identidade perceptível. Já na década de 90, a maior parte dos readers introdutórios a novas propostas teóricas da literatura capitulou diante da intransparência da própria casa. Em 1994, H. Aram Veeser apresentou o New Historicism em termos de diáspora concluindo que apenas "a mad desire could motivate the doomed effort to marshall together the best of the New Historicism". Mas agrupar e definir "these wildly individual efforts would demand an even crazier yearning" (Veeser, 1994: 1). Cinco anos antes, por ocasião da primeira publicação de uma coletânea sobre o assunto, o autor já tinha sido considerado intrépido porque os assim nomeados new historicists acentuaram a sua independência - e sua dissidência - em relação a projetos programáticos consensuais. Não se tratava, igualmente, de um movimento de uma prática compartilhada que destacasse o fenômeno em sua indeterminação. Ao contrário, a própria invenção do nome parecia virtualmente acidental e, na verdade, batizando algo "without an adequate referent"(1). Essa confissão de crise de identidade coletiva e falta de capacidade e vontade de enfrentá-la - aqui apenas exemplificada pelo New Historicism - passou a ser uma espécie de manifesto unificador nas teorias contemporâneas da literatura, frouxamente agrupáveis como "poéticas no plural" (Leitch, 1992:83-103).

$\mathrm{Na}$ Alemanha, uma das várias obras coletivas recentes de "textos fundamentais para a compreensão sistemática e propedêutica de categorias imprescindíveis para o estudo atual da literatura", inicia-se com uma afirmação sintomática e contundente dos organizadores. Segundo Fohrmann e Müller, o objeto da ciência da literatura não existe simplesmente. Ao contrário, ficou evidente para a própria disciplina que a tarefa 
básica precisava incluir o constante processo de redesenhar o(s) campo(s) do(s) objeto(s) de sua reflexão. Uma tarefa vista como alto risco à medida que mesclava aleatoriamente sentimentos de "felicidade e pavor" (Fohrmann e Müller, 1995: 7). A promessa de encanto pela constante inovação reflexiva assusta pelo impossível desenvolvimento de um saber cumulativo, linear. Desde os anos 70, a consciência aguda da falta de confiança em fundamentos visíveis e assumíveis estava, para uns, associada à insuportável sensação de perda e provisoriedade. Já outros, militantes no cenário dos estudos de literatura, sentem-se, ao contrário, estimulados pela oportunidade de infindáveis observações e auto-reflexões acerca das práticas de uma disciplina que, de modo geral, ainda se entende como dedicada aos estudos de literatura.

As dificuldades situam-se, assim, entre o discurso oscilante sobre literatura, os pressupostos epistemológicos, metateóricos, teóricos e metodológicos, e a necessidade simultânea de parar o fluxo e propor classificações, construções de sentido, pelo menos para que estas permitam certa homogeneização, favorecendo o entendimento do fenômeno literário, pelo menos, como convenção comunicativa e/ou ação social e cultural específica. A multiplicidade das questões sugeridas desafia práticas tradicionais a partir do instante em que o comportamento sensocomunal da disciplina se afasta da idéia de que o seu campo possa ser definido exclusivamente a partir de objetos verbais precisos ou propriedades substanciais de obras literárias. Segundo os autores citados, e não só eles, o universo da teoria da literatura, transferido para uma nova unidade fundante texto-contexto numa perspectiva pragmática, torna-se especialmente desafiante quando ensaia definições de fronteira entre arquivos próprios e alheios. Construções de sentido dependem dessas opções momentâneas cristalizadas por convenções consensuais que esboçam possíveis limites (Fohrmann e Müller, 1995: 9). Como se poderiam escrever hoje, então, histórias de literatura no horizonte dessas novas perspectivas e convicções?

À constelação dessas indagações, assinaladas pela emergência de incontáveis tratados teóricos sobre o assunto, não correspondem, nitidamente, o mesmo entusiasmo e o mesmo empenho quando se trata de sugerir alianças efetivas entre teorias inovadoras e práticas condizentes. A relação entre ambas caracteriza-se por uma óbvia dissincronia, às vezes por um abismo. Não é raro que propostas teóricas preservem o confortável estatuto de projetos não concretizados e sequer concretizáveis. E raramente a escrita de histórias de literatura cumpre as promessas programáticas acentuadas convictamente nas páginas introdutórias. Mesmo assim, podemos registrar interesses eventuais por práticas historiográficas da literatura que enfatizam expressa- 
mente o desejo de sintonia, não só com orientações teóricas e metodológicas alternativas da ciência da literatura discutidas desde o início da década de 70, mas igualmente com querelas, antes de caráter epistemológico, na teoria da história. O seu sucesso junto a um público profissional e leigo sugere igualmente algumas reflexões sobre as mudanças propostas por uma série de novas historiografias de caráter experimental, em circulação no final dos anos 80 e durante a década de 90 .

A questão subjacente às minhas reflexões sobre o tópico "histórias de literatura hoje" vincula-se à curiosidade quanto aos motivos capazes, ainda, de mobilizar os seus produtores, num momento de ceticismo radical em relação não só à capacidade representacional de sua própria escrita, mas igualmente em relação a desejos, funções e efeitos que pudessem legitimar o seu gesto. A rediscussão crítica da história da literatura, a partir do final dos anos 60 , geralmente relacionada com a publicação do hoje canônico texto de Hans Robert Jauss, Literaturgeschichte als Provokation der Literaturwissenschaft (1967), foi de certo modo co-responsável pela substituição de teses monocausais e globalizantes, e, também, de conceitos evolutivos lineares a favor de explicações multicausais, funcionais e estruturais, na formulação de modelos teóricos inovadores para os complexos processos de transformação do fenômeno literário.

Foi mérito desse ensaio programático ter estimulado a desconfiança diante de propostas explicativas clássicas de uma história sintética, universalista e totalizante, enquanto encadeamento cumulativo unilinear representável por uma estrutura narrativa, e de uma história da literatura até então identificada a partir do repertório de obras e autores enfileirados cronologicamente em uma utopia progressista, legitimada, de certo modo, pela suposição da existência de estilos e épocas algo homogêneas. Ao mesmo tempo, o comprometimento com modelos fundados sobre o singular coletivo literatura e sobre o singular coletivo história foi substituído por perspectivas que assinalam a historicidade do fenômeno literário, situando-o em uma esfera comunicativa de interação complexa, inicialmente a partir da relação texto/leitor como nova unidade fundante. Além de criticar a percepção substancialista da literatura reduzida à obra, essa nova proposta desorganizava margens até então não percebidas como problemáticas. A dimensão ampliada não só envolve o diálogo entre texto e receptor, em um contexto histórico datado, e os momentos de produção e recepção sob forma de horizontes de expectativa, como tematiza explicitamente a figura do observador/ historiador enquanto instância inserida em estruturas institucionais de saber e poder. 
O inegável valor motivador, sem precedentes, do repertório de Hans Robert Jauss não impediu, no entanto, que uma série de sugestões se tornasse problemática para o olhar atual, porque nos anos subsequentes, o interesse nos estudos da literatura deslocou-se mais claramente ainda do texto literário para questões relativas à situação circunstanciada do receptor e a sua referência institucional, ambas formadas por múltiplos reguladores da esfera cultural, política e social, ou seja, para uma definição pragmática mais explícita da literatura localizada em espaços geo-políticos concretos. Uma das questões mais candentes de sua proposta foi claramente uma reiterada confiança depositada no valor da literatura e, portanto, na sua história, que ele pretendia revigorar no final dos anos 60 . O título original do ensaio "O que significa e com que fim se estuda história da literatura?” foi uma atualização e adaptação para a literatura de uma pergunta formulada por Schiller em 1789, por ocasião da sua própria aula inaugural na universidade de Jena. Enquanto Schiller tinha vinculado, então, a vocação do historiador com a tarefa de oferecer ensinamentos ao indivíduo pensante, modelos ao homem prático, esclarecimentos ao filósofo e entretenimento ao leitor, Jauss, duzentos anos depois, formula mais uma vez o compromisso em torno do projeto iluminista, nos seguintes termos: à história da literatura cabe uma função verdadeiramente constitutiva da sociedade, "concorrendo com as outras artes e forças sociais, na emancipação do homem de seus laços naturais, religiosos e sociais" (Jauss, 1996: 57). Uma função, segundo o autor, resgatável pela superação do abismo entre literatura e história, entre conhecimento estético e conhecimento histórico. Menos de três décadas depois, há poucos que assinariam de bom grado semelhante contrato, não enquanto declaração de intenções e muito menos enquanto realização prática. Como explicar tamanho desinteresse e desprestígio?

A década de 70 , segundo certo consenso na área, passará para a história dos estudos da literatura, provavelmente, como um período especialmente ocupado com a escrita de novas histórias da literatura, ainda que entre teorização e prática historiográfica existisse um abismo. Na Alemanha, um comentário avaliador de Siegfried Schmidt sobre o desequilíbrio neste campo, entre produção teórica e prática, oferece uma visão dos compromissos que, em princípio, deveriam ser assumidos neste projeto. "Presumo que o conjunto de limitações práticas, ligadas à realização de histórias literárias planejadas, contribui para um tratamento, por parte dos colaboradores, mais ou menos pragmático dos problemas fundamentais relativos a novas histórias da literatura. Talvez esses estudiosos estivessem corretos em sua decisão: a sociedade parecia necessitar de novas histórias da literatura e, por conseguinte, as discussões sobre 
questões aparentemente sem resposta fossem subordinadas a um preenchimento imediato da necessidade social. Mas, no momento em que as editoras já estão esgotando a venda dos novos produtos, deveríamos sentir a obrigação de voltar a uma reflexão mais paciente e demorada sobre os fundamentos da escrita de histórias literárias" (Schmidt 1996: 51).

O resultado prático dessas novas reflexões e convicções epistemológicas e metateóricas, no caso de Schmidt, encontra-se exposto em dois experimentos para novas histórias da literatura que ensaiam uma espécie de casamento insolúvel entre teoria e prática. O primeiro, de 1983, intitula-se Das Voraussetzungssystem Georg Trakls, e foi escrito em parceria com Gebhard Rusch. O segundo, de 1989, se chama Die Selbstorganization des Sozialsystems Literatur im 18. Jabrbundert. Ambos os experimentos, de dimensão e esforço gigantescos, tiveram uma recepção gratificante por parte de especialistas no assunto, ainda que estes não necessariamente apreciassem o repertório intelectual subjacente baseado em teorias construtivistas radicais privilegiadas pelo modelo de uma ciência da literatura empírica que atribuía à interpretação de obras literárias particulares um entre muitos outros lugares - possíveis e desejáveis a serem ocupados pelo olhar curioso de estudiosos do fenômeno literário. Em relação ao público alvo talvez desejado, os autores tiveram que computar um fracasso certamente indesejado. $\mathrm{O}$ que era deleite para uma gulosa comunidade científica às voltas com uma teorização complexa em função de pressupostos epistemológicos alterados, constituía dificuldade, estranhamento e pesadelo para o amador ou iniciante neste delicado campo de estudos, onde até hoje não se sabe ao certo onde situar as nossas razões, sensibilidades e intuições. $\mathrm{O}$ que não significa necessariamente o abandono de um empreendimento teórico que entende como tarefa mais importante a construção de uma rede conceitual e sua aplicação, em contextos históricos concretos de ação, a um conjunto de fenômenos ou objetos. Em princípio, a meu ver, trata-se de um projeto louvável e urgente, ao deixar de identificar a teoria com uma rede conceitual e a sua representação verbal formal, a favor de uma forma pragmática, ou como diria Gebhard Rusch, da "representação de hipóteses em atos" (Rusch, 1995: 106).

O primeiro livro se apresenta, neste sentido, como experiência modelar. Baseado em um repertório de pressuposições teóricas construtivistas, oferece antes um guia para o iniciante entender o emaranhado complexo epistemológico, metateórico, teórico e metodológico que sustentava o desejo de oferecer uma história da literatura em sintonia com o mais avançado estágio de reflexões teóricas na década de 80 , exemplificado, no caso, por um chamado experimento de biografia literária. A pergun- 
ta subjacente se formula mais ou menos assim: de que Trakl, afinal, estamos falando se entendemos a historiografia literária como trabalho de construção? O material empírico arrolado para simular o casamento compulsório é gigantesco, porque Georg Trakl tornou-se objeto de incontáveis interpretações, descrições e explicações das mais controversas no contexto de estudos literários, práticas biográficas e obras historiográficas. Se aliarmos a essas descrições ainda as da imagem pessoal formada por amigos e contemporâneos, emerge uma impressão cintilante e oscilante de sua personalidade: tão somente imagens de Trakl.

Essas imagens devem ser vistas como facetas, fragmentos de uma personalidade complexa que uma síntese oferecida pela história literária transformaria numa imagem coesa, autêntica, ou será que elas encontram-se sem nexo uma ao lado da outra, como quadros no museu? A resposta não é só induzida pelas opções teóricas, mas igualmente pelo material empírico armazenado em forma de listagens e referências, não seguindo, além da ordem cronológica, nenhuma outra ordenação aparente. Os interessados na composição de uma imagem - entre infinitas outras, nenhuma delas se habilitando à categoria da verdade, unidade, totalidade - podem escolher o seu material e a forma do seu arranjo, de acordo com os seus próprios interesses e compromissos variados. Schmidt e Rusch tentam esboçar, assim, uma alternativa para compor imagens de Trakl, ao privilegiarem fundamentos construtivistas, ao explicitarem as suas escolhas teóricas e orientarem o trabalho numa perspectiva empírica não positivista. O que neste contexto singulariza, ou deveria singularizar, um projeto historiográfico no campo dos estudos literários - portanto uma esfera de atuação científica disciplinar que, em princípio, se diferencia, em sua demanda de mecanismos de construção, dos hábitos envolvidos na experiência cotidiana - seria precisamente uma sistematização e explicitação dos pressupostos de sua ação.

Na prática, aparentemente, a dissociação dessas duas esferas perturba e constrange tanto os leigos quanto os profissionais. Os primeiros preferem uma experiência viva; os segundos, os espaços do mundo e dos arquivos e, eventualmente, o retiro para as esferas intelectuais da reflexão. Mas geralmente trata-se de experiências divorciadas a não ser para os próprios autores afinados em longa convivência e socialização em espaços acadêmicos similares. Como situar, então, alternativas interessantes e aceitáveis de acordo com novos pressupostos para não desistir da escrita de histórias da literatura?

Uma série de novas propostas historiográficas publicada nos Estados Uunidos exibe explicitamente a marca de concordância com posturas e plausibilidades altera- 
das. Entre elas parecem-me exemplares, e dignas de comentário, três modelos de historiografia (literária) publicados nas décadas de 80 e 90 . No prefácio da Columbia Literary History of the United States (1988), os editores da obra coletiva diferenciam o seu projeto de anteriores, pela imagem emblemática de uma metáfora arquitetônica. Essa nova história da literatura, situada como "modestly postmodern" é construída como galeria de arte. Várias entradas disponíveis garantem o acesso aos diversos corredores. Em contraste com outras histórias, de caráter monumental e optando por um modo de representação linear e uniforme do passado, os seus princípios estruturais acentuam diversidade, complexidade e contradição, portanto, formas avessas a perspectivas globais, homogeneizantes. A partir desses compromissos, os editores assumem as contribuições dos diferentes autores em sua forma original sem intervenção sintetizadora que pudesse transformar a coletânea, de autoria e compromissos diversos, em narrativa linear e coerente.

Ao leitor, permite-se, desta forma, a experiência paradoxal do confronto com elementos articulados aleatoriamente numa estrutura harmônica ou dissonante sem síntese. Um procedimento condizente com hipóteses e diagnósticos recentes. Assim lemos, por exemplo, que hoje inexistem visões uniformes de uma identidade nacional e, por conseguinte, é preciso representar a multiplicidade coexistente das perspectivas da investigação contemporânea, reprimindo o desejo de vê-las unificadas. Neste sentido, comparecem, lado a lado, autores da linhagem canonizada e autores de tradições tão divergentes quanto "American Indian writers, black writers, women writers, Asian and American, Hispanic and Jewish-American writers" (1988: 24). Uma situação que obviamente proíbe falar de uma única história da literatura americana, o que o próprio título exibe com ênfase: Histórias de literatura dos Estados Unidos. Por outro lado, os editores homenageiam com este projeto as mudanças fundamentais do literary criticism dos últimos vinte e cinco anos motivadas, entre outras, pelas provações alemãs, francesas, inglesas e americanas, no campo dos pressupostos teóricos e epistemológicos que transformaram o ambiente da discussão acadêmica em cenário, de certo modo, selvagem e aberto.

O segundo projeto, A New History of French Literature (1989), representa um notável e inédito esforço coletivo neste tipo de empreendimento - além do organizador responsável, de um conselho editorial, de consultores específicos por assunto e época -, comparecem cento e sessenta e cinco ensaístas, de orientação filosófica divergente e de origens nacionais, geográficas, disciplinares, étnicas, raciais, e culturais não sintonizáveis. A New History of French Literature, sob a responsabilidade geral de Denis 
Hollier, uma obra de mil cento e cinqüenta e oito páginas, publicada pela editora da universidade de Harvard, foi recebida com entusiasmo por críticos de jornais, suplementos literários e periódicos especializados, e transformou-se de imediato em objeto de desejo de um público igualmente variado, evidenciado pelo inusitado sucesso de venda. "Plunge in and you will come up with pearls (...): Exciting, irritating, invigorating, often provocative, always interesting (...); The fact is that $A$ New History of French Literature has rendered its predecessors obsolete (Hollier 1989, contracapa). Se estes comentários não bastassem, o livro foi agraciado com o prêmio Winner of the Prix France-Amérique, e distinguido pela Modern Language Association como "The Best Book of the Year". Como entender esse insólito sucesso multidimensional?

O editor explica na introdução que a obra, idealizada para um leitor mediano, não apresenta a literatura francesa como simples inventário de autores e títulos, mas como campo histórico e cultural visto a partir de um imenso leque de perspectivas críticas contemporâneas. Segundo ele, nenhum dos modos tradicionais de apresentação enciclopédica - seja na forma de uma narrativa histórica contínua, seja na forma de um dicionário em ordem alfabética - parecia adequado para tal projeto. O primeiro, porque homogeneiza a literatura de modo artificial ordenando-a em genealogias lineares e o segundo, porque oferece uma massa de informações freqüentemente irrelevantes, no desejo de oferecer uma cobertura completa.

À medida que os ensaios se seguem, eles são introduzidos por determinada data seguindo uma ordem cronológica respeitando, neste aspecto, a forma de apresentação usual em histórias da literatura tradicionais. No entanto, "both individually and cumulatively question our conventional perception of the historical continuum. Each date is followed by a headline, evoking an event, which specifies not so much the essays content as its chronological point of departure. The event is literary - typically the publication of an original work, of a journal, or of a translation: the first performance of a play; the death of an author. But some events are literary only in terms of their repercussions, and some of those repercussions are fare removed from their origins in time or place. The juxtaposition of these events is designed to produce an effect of heterogeneity and to disrupt the traditional orderlines of most history of literature" (Hollier, 1989: xxiii).

O debate metodológico sobre a tarefa do historiador da literatura, segundo Denis Hollier em seu artigo introdutório "On Writing Literary History", se limitou, assim, à questão de opções para uma descrição das conexões entre o mundo interior e exterior da obra literária. De um modo geral, o resultado final revela o privilégio dado à de- 
monstração de certa independência da obra em relação a seu contexto ou acentuava um interesse particular por questões de evolução específica da literatura. Nos dois casos parecia evidente a manutenção da distinção entre uma esfera interior e exterior, demarcando as fronteiras onde a literatura começava e onde terminava. Contrariando os pressupostos substancialistas comuns nestas práticas, segundo Hollier, querer traçar limites estáveis tornou-se uma tarefa extremamente difícil, ingrata e provavelmente impossível. Para ele, então, mais um motivo para rejeitar a opção por modos de representação tradicionais como o da enciclopédia alfabeticamente ordenada e o da narrativa contínua.

A alternativa proposta por Hollier funda-se no princípio da montagem, do arranjo de fragmentos, sem pretensão de compor imagens unificadas. Assim, $A$ New History of French Literature consiste em torno de duzentos ensaios, arrumados em ordem cronológica de acordo com a data de determinados eventos. O primeiro ensaio, reportando a 778, tematiza a morte de Rolando, e o último, a 27 de setembro de 1985, intitulado Friday Night Books, refere-se a um talk-show popular sobre novas publicações literárias na televisão francesa. Portanto, o livro é concebido para produzir efeitos de heterogeneidade e dispersão, problematizando as categorias tradicionais da maioria das histórias de literatura que, ao contrário, procuram a síntese. E esta qualidade, presente também na Columbia Literary History of the United States, diferencia esses experimentos das marcas tradicionais dos congêneres anteriores, tanto em sua proposta temática quanto estrutural. E, deste modo, leitores - leigos e profissionais - são estimulados a compor o seu próprio menu individual e a participar de um circuito comunicativo por princípio aberto e interativo. Em suma, trata-se, em última análise, da transformação em prática historiográfica das reflexões epistemológicas, teóricas e metodológicas que mobilizaram teóricos e historiadores da literatura nas últimas três décadas.

O último exemplo, que merece ser lembrado, refere-se ao livro de Hans Ulrich Gumbrecht, In 1926. Living on the edge of time, publicado em 1997 pela Harvard University Press e traduzido em 1999 com o título Em 1926. Vivendo no limite do tempo. Este também chamado ensaio sobre simultaneidade histórica, transformou-se, nos Estados Unidos, em curioso best-seller de um público mais amplo, deixando, de certo modo perplexo, não só o autor mas igualmente o limitado círculo dos destinatários tradicionais da profissão, certamente desconfiados e desconcertados diante desse tipo de sucesso. 
O livro, de umas quinhentas páginas e de autoria única - que escolhe um ano banal, 1926, como unidade temporal puramente convencional, para criar uma atmosfera capaz de produzir no leitor uma noção de como deve ter sido estar vivo naquele momento - oferece de início um manual de instruções ao usuário com a seguinte recomendação: "Não tente começar do começo, pois este livro não tem começo, no sentido em que têm as narrativas ou discussões" (1999: 9). Segue-se uma advertência para o leitor desavisado que se defronta com cinqüenta e um verbetes distribuídas em três seções intituladas dispositivos, códigos e códigos em colapso. O privilégio dado à ordem alfabética pretende salientar, tão somente, a ausência intencional de qualquer estruturação hierárquica e cronológica, o que transforma esses verbetes, de imediato, em nós de uma imensa rede de referências transversais que, a exemplo de hiper-textos, facultam ao leitor escolhas e caminhadas sem direção e fim. E sem previsão de tempo. "Leia no ritmo que o seu interesse determinar e na medida em que sua agenda permitir" (p. 9). O efeito pretendido de uma experiência material não mediada - você deve se sentir em 1926 - impõe-se pela própria escolha de acentuado estilo descritivo, no presente, que prioriza radicalmente percepções de superfície e concretude proporcionadas por fenômenos materiais e visões de mundo dominantes em oposição à interpretação profunda e da contextualização diacrônica, vistas como modos de expressão em concordância com o estilo narrativo e a presença de uma voz autoral intencional que constrói sentido. Um segundo impacto alia-se a essa primeira opção: o que fazer do conhecimento histórico se acreditamos que a tese de que "podemos aprender com a história" perdeu o seu poder de persuasão? (Gumbrecht, 1999: 459). Para o autor não se colocam funções edificantes, moral ou politicamente. Mas se hoje questionamos a função didática tradicional da história - uma função que parece fortemente relacionada com o hábito de pensar e representar a história como seqüência narrativa- seria necessário elaborar simultaneamente novas funções e formas de representação para uma historiografia não-narrativa. "Precisamos inventar modos diferentes de usar o nossos conhecimento histórico e não repetir apenas o seu valor didático”, diria Gumbrecht no apêndice (p. 462). Ele aventa, então, a hipótese de que, talvez por falta de legitimações mais racionais plausíveis e convincentes, ainda pudéssemos admitir que o que nos leva a reconstruir o passado é o nosso desejo impossível de uma vivência direta de mundos que existiram antes de nós nascermos. Neste contexto, a vivência direta do passado implica o desejo de tocar, cheirar e provar estes mundos passados através dos objetos que os constituíram, reivindi- 
cando um lado sensorial da experiência histórica até então profundamente marginalizado e subestimado (Gumbrecht, 1999: 467).

Esse, segundo o autor, seria talvez um meio produtivo para recuperar algum uso para todo o conhecimento que tão freneticamente produzimos, preservamos e ensinamos sobre o passado. O deslocamento do reino das idéias, das representações racionais guiado por projetos edificantes se daria, então, a favor de uma história no espaço das vivências e experiências concretas da vida cotidiana em sua materialidade sensorial. O que dispensa igualmente o esforço, impossível, de regular o mundo caótico da experiência vivencial a partir de categorias ordenadas. Mais um argumento para desenfatizar uma escrita espelhada na estrutura narrativa.

No livro de Gumbrecht transparecem variadas indicações, que situam os seus compromissos claramente em sintonia com uma situação acadêmica e intelectual específica, que corresponde ao que "nós (pessoas educadas dentro da cultura ocidental de 1997)" imaginamos ser história enquanto participantes da discussão mais avançada no campo disciplinar e profissional da história/historiografia a que pertencemos (1999: 11). Antes de mais nada, trata-se de novas convicções epistemológicas compartilhadas acerca da história e de suas formas de representação. A negação de uma história de estrutura unilinear e totalizante e o privilégio dado a uma representação sincrônica isenta da seqüencialidade, tornam este livro, classificado pelo autor de ensaio sobre simultaneidades, incompatível com idéias de coerência e síntese. Ao invés delas é sugerido o modelo de rede ou de campos de realidades, não apenas discursivas, que moldam condutas e interações no ano de 1926. Não é por acaso que, neste contexto, a figura do rizoma é evocada com insistência.

Uma imagem emblemática dessa sensação de simultaneidade encontra-se no ensaio "nachMODERNEZEITENräume", de 1991, do mesmo autor. Uma das razões que motivam as suas reflexões pode ser traduzida como desconfiança em relação à filosofia e às ciências humanas que, contrariando expectativas gerais, não ocupam posição de vanguarda no pensamento atual, o que, segundo ele, se revela no fato de que mesmo no final deste século, ainda não assimilaram plenamente um pensamento nachmodern. Um dos objetivos do ensaio pode ser visto, então, na tentativa de mostrar como na perspectiva nachmoderne da vida cotidiana, - em oposição às teorias acadêmicas institucionalizadas - as dimensões espaço-temporais, há muito, são experimentadas em movimento, sem que essas mudanças tivessem causado quaisquer dificuldades dramáticas de adaptação . 
As novas experiências são ilustradas por Gumbrecht a partir do mundo dos saguões nos aeroportos. Para os passageiros em trânsito, ainda que o aeroporto de Nova York se encontre ao seu alcance atual - simultaneamente apreensível pela consciência e pelo corpo - ele, na verdade, é experimentado como alcance potencial, à medida que os saguões dos aeroportos são espaços sem nome que não se vinculam com determinada cidade mas, antes, com todos os outros saguões do mundo. Se a hipótese for correta, esse tipo de espaço - locais de trânsito ou de distribuição - encontra-se hoje no centro de nossa experiência de vida. Além desses deslocamentos na experiência de nossas zonas espaciais cotidianas, algo semelhante ocorre com respeito a nossas zonas temporais. Elas se mesclam constantemente, fazendo com que os nossos corpos transitem simultaneamente em tempos distintos. No exemplo de Gumbrecht, o aeroporto Kennedy transforma-se em espaço de temporalidades altamente complexas. "Suponhamos que o nosso passageiro, chegando da Europa, tenha tomado o café da manhã ainda na Europa e, tendo tomado o segundo café da manhã no avião , sente então vontade de almoçar, esse seu apetite corresponderia a um tempo social que o seu corpo trouxe da Europa. No caso, ele estaria, por assim dizer, espacialmente presente no corpo do passageiro, mas em conflito com o tempo local dos empregados do restaurante do saguão que - tão cedo em sua manhã - só oferecem café e sanduíche de queijo. A esses tempos, de nossa situação inventada, acrescentam-se ainda, no espaço único do saguão de trânsito, os tempos dos passageiros vindos da costa ocidental dos Estados Unidos, e que são visíveis nos rostos cansados dos madrugadores"(Gumbrecht, 1991: 58). Se acrescentarmos a essa situação, ainda, os vários relógios encontráveis na maioria dos terminais indicando simultaneamente zonas temporais distintas, correspondentes aos respectivos fusos horários, teremos uma temporalidade radicalmente complexa. Junto com a espacialidade em trânsito, ela contribui para uma nítida sensação de aleatoriedade contrária à direção do viajante que se desloca de um espaço de partida para um espaço de chegada, e essa sensação parece dissolver a sua intencionalidade e a sua linearidade.

Essas novas experiências sinalizam mudanças fundamentais em nossa constituição e vivência espaço-temporais e mostram a dificuldade em descrevê-las, porque os nossos repertórios conceituais disponíveis são totalmente incapazes de apreender aquilo que, em nossa vida cotidiana nachmoderne, há muito já se tornou trivial. Os novos esboços conceituais para estas temporalidades e espacialidades nachmoderne precisam incluir estruturas de experiência levando em consideração os múltiplos níveis do tempo e do espaço social (p. 62). Em vez de deixarmos o presente para trás, 
nós o empurramos, por assim dizer, em direção ao futuro. $\mathrm{E}$ ao mesmo tempo, os espaços do passado passam a ser reproduzidos, no presente, numa perfeição técnica antes inimaginável. Dois movimentos, tanto o deslocamento do futuro próximo para um futuro distante, quanto o preenchimento do presente com múltiplos passados, convergem, portanto, na impressão de que o presente ampliou o seu espaço no tempo nachmodern, encontrando-se em constante expansão. Nesta hipótese o tempo nachmodern não é meramente uma nova época na seqüência linear do tempo, porque a construção de épocas, em constantes processos de substituição, tornou-se improvável. O tempo, enquanto tempo histórico, parece ter parado o seu movimento num presente de horizonte cada vez mais abrangente e aberto e, ao mesmo tempo, ele parece estar atravessado por movimentos cada vez mais velozes, numa pluralidade de tempos de presença simultânea.

Para leitores de interesses profissionais, o livro oferece, sob forma de apêndice, uma dupla contextualização. Gumbrecht enuncia, aí, explicitamente os seus vínculos com uma discussão acadêmica e intelectual atualizada no campo das ciências humanas, responsável pela escolha de conceitos contemporâneos plausíveis e aceitáveis para o experimento historiográfico que o projeto ensaia. Se dele não fazem parte, portanto, propósitos edificantes para o conhecimento histórico, o experimento - cujo universo referencial não apenas literário, do espaço de um ano, estende-se aos mais variados objetos, experiências e fenômenos culturais, políticos e sociais do mundo em 1926, tais como aviões, automóveis, transatlânticos, americanos em Paris, bares, dancings, revistas, jaح‡, boxe, touradas, gramofone, telefone, comunicação sem fio, greve e artistas de fome - faz-se acompanhar, em compensação, por uma densa discussão teórica e pela legitimação de pressupostos de parcialidade, perspectividade, objetividade, relatividade e construtividade, conceitos que, de certo modo, se transformaram em repertório sensocomunal das reflexões recentes sobre novas formas de escrever histórias de literatura e também, sobre a prática dos empreendimentos historiográficos efetivamente concretizados. Se vincularmos com este repertório o convite do autor para uma radicalização dos seus resultados - um argumento que articula os nossos processos de conhecimento com o presente - entendemos talvez parte do novo cenário intelectual que abriga as nossas curiosidades e perplexidades sem o menor conforto da síntese.

Em todo o caso, os exemplos analisados de uma nova escrita historiográfica revelam de forma inquestionável o desejo de diminuir o descompasso entre uma 
teorização complexa e uma prática, de certo modo, alheia às discussões atuais na esfera da teoria da história e da teoria da literatura.

Se, além do mais, damos crédito ao interesse e ao sucesso desses experimentos, não só junto a um círculo restrito de especialistas mas junto a um público amplo, estamos diante de um fenômeno que ensaia na prática o difícil casamento entre o recinto fechado da academia e o espaço extra-muros onde se demanda uma pedagogia inovadora que, além da construção de conceitos em um processo racional, saiba revigorar, ao mesmo tempo, uma experiência viva fundada no desejo de tocar, cheirar e provar os objetos de investigação de nossa curiosidade científica.

\section{$\operatorname{soc}$}

\section{REFERÊNCIAS BIBLIOGRÁFICAS}

ELLIOT, T. et alii. Columbia literary bistory of the United States. New York: Columbia UP, 1988.

FOHRMANN, J. e H. MÜLLER (eds.). Literaturwissenschaft. München:Fink, 1995.

GUMBRECHT, Hans Ulrich. In 1926. Living on the edge of time. Cambridge: Harvard, UP, 1997.

GUMBRECHT, Hans Ulrich. Em 1926. Vivendo no limite do tempo. São Paulo: Record, 1999.

GUMBRECHT, Hans Ulrich. "nachMODERNEZEITENräume". In: e R. Weimann (eds.). Postmoderne; globale Differen₹. Frankfurt:Suhrkamp, 1991, p.54-70.

HOLLIER, Denis. "On Writing Literary History”. In: __. (org.). A new bistory of French Literature. Cambridge: Harvard UP, 1989, p. xxi-xxv.

HEILBIG, Jörn. "Der Rezipient als Cybernaut”. In:___ (ed). Intermedialität. Berlin:Erich Schmidt, 1998, p.81-92.

JAUSS, Hans Robert. Literaturgeschichte als Provokation der Literaturwissenschaft. Konstanzer Universitätsreden, n.3, 1967.

JAUSS, Hans Robert. História literária como provocação à teoria literária. São Paulo: Ática, 1996.

LEGOFF, Jacques.”Prefácio”. In:___ (org.). A nova história. Martins Fontes: São Paulo,1990.

LEITCH, Vincent B. Cultural criticism, literary theory, poststructuralism. New York: Columbia UP, 1992.

LUKÁCS, Georg. Significado presente do realismo crítico. Lisboa: Cadernos de Hoje, 1957.

PEPPER, Jürgen. "Postmodernism: Unitary sensibility (Von der geschichtlichen Ordnung zum synchronenvironmentalen System)". In: Manfred Pütz e Peter Freese (eds.) Postmodernism in American Literature. Darmstadt:Thesen Verlag, 1984, p. 167-193.

RÜSEN, Jörn. "A história entre a modernidade e a pós-modernidade”. História:Questões e Debates. v.14,n.26/ 27, jan./dez. 1997, p. 80-101.

RUSCH, Gebhard. "The notion of 'empírical': Knowing How." In: (org). Empirical Approaches to literature. Siegen: Lumis-Publications, 1995, p. 103-108.

SCHMIDT, Siegfried J. Die Selbstorganisation des Sozialsystems Literatur im 18. Jahrbundert. Frankfurt: Suhrkamp, 1989. 
SCHMIDT, Siegfried J."Sobre a escrita de historias da literatura". In: OLINTO, Heidrun Krieger (org.) Historias de literatura. As novas teorias alemãs. São Paulo: Ática, 1996, p. 101-132.

SCHMIDT, Siegfried J e Gebhard Rusch. Das Voraussetzungssystem Georg Trakls. Braunschweig, Wiesbaden, Vieweg, 1983.

SONTAG, Susan. "Uma cultura e a nova sensibilidade". In: Contra a interpretação. Porto Alegre: L\&PM, 1987, p.338-350.

VEESER, H. Aram (ed.). The New Historicism Reader. New York: Columbia UP, 1994.

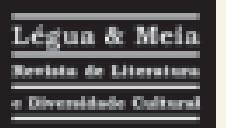

OLINTO, Heidrun Krieger. Histórias de Literatura: conflitos e caminhos. Légua \&o meia: Revista de literatura e diversidade cultural. Feira de Santana: UEFS, n 1, 2002, p. 35-53.

Heidrun Krieger Olinto é Professora Associada da PUC-Rio. Graduada em Letras pela PUC-Rio, Mestre e Doutora pela UFRJ, Pós-Doutorado na Universidade de Bremen, Alemanha. Publicou, dentre outros livros, Histórias de literatura (1996), Novas Epistemologias (org. com Karl Erik Schollhammer, 2000), Literatura e Midia (org. com Karl Erik Schollhammer, 2001) e Como falar de literatura hoje? (2001). É editora da revista Palavra. 